\title{
Interviews Conducted by Author
}

Interview A, with an American Asatruer, 2004. Interview B, with an American Asatruer, 2004. Interview C, with an American Asatruer, 2004. Interview D, with a German Asatruer, 2010. Interview E, with a German Asatruer, 2010. Interview F, with a German Asatruer, 2010. Interview G, with a Danish Asatruer, 2010. Interview H, with a Danish Asatruer, 2010. Interview I, with a Danish Asatruer, 2010. Interview J, with a Danish Asatruer, 2010. Interview K, with Danish Asatruers, 2010. Interview L, with a German Asatruer, 2010. Interview M, with a German Asatruer, 2010. Interview N, with a German Asatruer, 2010. Interview O, with a Norwegian Asatruer, 2010. Interview $\mathrm{P}$, with two Norwegian Asatruers, 2010. Interview Q, with a Norwegian Asatruer, 2010. Interview R, with a Norwegian Asatruer, 2010. Interview S, with an Icelandic Asatruer, 2010. Interview T, with an Icelandic Asatruer, 2010. Interview U, with an Icelandic Asatruer, 2010. Interview V, with a Danish Asatruer, 2010. Interview W, with a Swedish Asatruer, 2010. Interview with Uwe Ehrenhöfer (Eldaring), March 11, 2010. Interview with Søren Fisker and Lars Irenessøn (Forn Siðr), April 13, 2010. Interview with Haimo Grebenstein (VfgH), May 04, 2010. Interview with Henrik Hallgren (Samfundet Forn Sed), August 28, 2010. Interview with Jóhanna Harðardóttir (Ásatrúarfélagið), August 12, 2010. Interview with Ivar Hille (Foreningen Forn Sed), February 25, 2010. Interview with Óttar Ottóson (Ásatrúarfélagið), August 11, 2010. Interview with Arne Sjöberg (Breidablikk-Gildet), 1991. Interview with Egil Stenseth (Bifrost), February 22, 2010. Interview with six members of Nornirs Ætt, May 9, 2010. 


\section{Correspondences with Author}

Correspondence with Stephan Grundy (The Troth), 2011 and 2014.

Correspondence with Hilmar Örn Hilmarsson (Ásatrúarfélagið), 2012.

Correspondence with Pete Jennings (Odinshof), 2010.

Correspondence with Duke Meyer (Nornirs Ætt), 2010

Correspondence with Alan Nash (Kith of Yggdrasil), 2010.

Correspondence with Kurt Oertel (Eldaring), 2010. 